\title{
ENHANCEMENT OF GROWTH IN ORNAMENTAL PEPPER (CAPSICUM ANNUUM L.) PLANTS WITH APPLICATION OF A COMMERCIAL SEAWEED PRODUCT, STIMPLEX ${ }^{\circledR}$
}

\author{
OZBAY, N. ${ }^{1 *}-$ DEMIRKIRAN, A. R. ${ }^{2}$ \\ ${ }^{1}$ Bingol University, Department of Horticulture, Bingol, Turkey \\ ${ }^{2}$ Bingol University, Department of Soil Science and Plant Nutrition, Bingo, Turkey \\ (phone: +90-537-2018-8314; fax: +90-426-216-0029) \\ *Corresponding author \\ e-mail: oznusret@yahoo.com
}

(Received $8^{\text {th }}$ Jan 2019; accepted $22^{\text {nd }}$ Feb 2019)

\begin{abstract}
Seaweed extracts have been used as biostimulant or biofertilizers in agriculture to improve growth and development in plants, and enhance yield. There are a wide variety of commercial seaweed products for use on plant growth promotion. In this study, a greenhouse experiment was carried out to evaluate the effect of Stimplex ${ }^{\circledR}$, a commercial liquid seaweed extract derived from Ascophyllum nodosum, on growth of ornamental pepper (Capsicum апnиum L.) plants. Containing a complex array of bioactive compounds, Stimplex ${ }^{\circledR}$ is a premium organic biostimulant that promotes the growth, development, and yield in a wide range of conventional and organic grown horticultural and ornamental crops. Ornamental pepper plants were treated with Stimplex ${ }^{\circledR}$ as either a soil drench or foliar spray at 0 , $0.25,0.50,0.75$, and $1.0 \mathrm{ml} \cdot \mathrm{L}^{-1}$ concentrations. The treatments were repeated at 10-day intervals until the end of the experiment. Application of Stimplex ${ }^{\circledR}$ to ornamental pepper plants improved stem diameter, plant height, number of leaves and leaf area, leaf chlorophyll content, shoot fresh weight, shoot dry weight, root fresh weight and dry weight compared to the control plants. The results of this study indicate that Stimple $x^{\circledR}$ may be a viable tool for improving growth of ornamental pepper plants.
\end{abstract}

Keywords: Ascophyllum nodosum, sustainable, biostimulant, relative chlorophyll content, biofertilizer

\section{Introduction}

It is necessary to develop sustainable alternatives for agricultural production because of the growing consumer demand for agricultural products, increased costs of chemical fertilizers, and more importantly the detrimental effects of the residuals from chemical fertilizers and pesticides. In recent years, the use of biostimulants to promote plant growth in sustainable agriculture has gained increasing attention worldwide (Nardi et al., 2016). The use of biostimulants in agriculture has been estimated to increase at an annual rate of $13.58 \%$ during the forecast period, 2017-2022 and it is projected that the global market for biostimulants will reach to $\$ 3.68$ billion in annual revenue by 2022 (Anonymous, 2017). Kauffman et al. (2007) defined the word biostimulant as "biostimulants are materials, other than fertilizers, that promote plant growth when applied in low quantities." Companies in the biostimulant sector have created an association called 'European Biostimulants Industry Council' (EBIC) in Europe. The EBIC proposes the following definition for the biostimulant: Plant biostimulants contain substance(s) and/or microorganisms whose function when applied to plants or the rhizosphere is to stimulate natural processes to enhance/benefit nutrient uptake, nutrient efficiency, tolerance to abiotic stress, and crop quality (EBIC, 2018). A wide range of compounds, including humic and fulvic acids, seaweed extracts, protein hydrolysates and other $\mathrm{N}$-containing compounds, chitosan and other biopolymers, beneficial 
microorganisms, and other potentially bioactive agents act as a biostimulant (Calvo et al., 2014; du Jardin, 2015). There are broad variety of commercial biostimulant products are available for use on plant growth promotion. One of these commercial products is Stimplex ${ }^{\circledR}$. It is a concentrated liquid crop biostimulant extracted from seaweed (Ascophyllum nodosum) which stimulates plant growth and development, promotes yield, earlier maturity, improves resistance to some environmental stresses, improves fruit quality, increases fruit set in a wide range of conventional and organic grown horticultural and ornamental crops (Crouch et al., 1992; Zhang and Ervin, 2004; Spann and Little, 2010; Sidhu and Nanswani, 2016). Stimplex ${ }^{\circledR}$ contains trace amounts of some elements, vitamins, amino acids, auxins, cytokinins and natural chelating agents such as mannitol, fucoidins and alginic acids. It also induces the plant's own production of natural growth substances such as auxins and cytokinins to stimulate cell division and cell elongation initiating the development of larger root systems and promoting growth and yield (Crouch et al., 1992; Crouch and van Staden, 1993; Reitz and Trumble, 1996; Stirk et al., 2003; Spann and Little, 2010; du Jardin, 2015; Anonymous, 2018). Numerous studies have revealed that seaweed extracts promoted growth, increased yield and quality of horticultural crops such as grapes (Norrie and Keathley, 2006), apple (Basak, 2008), olives (Chouliaras et al., 2009), watermelon (Adbel-Mawgoud et al., 2010), cucumber (Sarhan et al., 2011), broccoli (Mattner et al., 2013), spinach (Fan et al., 2013), eggplant (Nandwani et al., 2015), strawberry (Nika et al., 2018), maize (Zermeno-Gonzalez et al., 2015), and tomato (Hernández-Herrera et al., 2014; Ali et al., 2016; Sidhu and Nandwani, 2017). To our knowledge no information on the application of Stimplex ${ }^{\circledR}$ to ornamental pepper plants has been published. The objective of the present research was to determine effective doses and application methods of Stimplex ${ }^{\circledR}$, a commercial liquid extract of Ascophyllum nodosum, on growth of the ornamental pepper (Capsicum annuum L.) plants.

\section{Materials and methods}

\section{Location and characteristics of the study area}

The greenhouse experiment was conducted during the spring-summer 2016 at the Agricultural Sciences Research Center of Bingol University, in Bingol, Turkey $\left(38^{\circ} 53^{\prime} \mathrm{N}, 40^{\circ} 29^{\prime} \mathrm{E}\right.$, at $1139 \mathrm{~m}$ altitude). The experiment was carried out in heated polycarbonate-covered greenhouse with natural daylight conditions at average day/night temperature of $29 / 18{ }^{\circ} \mathrm{C}$ and relative humidity of $60 \%$.

\section{Plant material}

Seeds of ornamental pepper (cv. 'Thai Hot') were used as plant material. The 'Thai Hot' ornamental pepper plants are compact, and grow up $30 \mathrm{~cm}$ tall. The fruits on them grow up to $2.5 \mathrm{~cm}$ long, point upwards from the plant. It matures abut 80-85 days. This variety produces large numbers of fruits (averages 200 fruits per plant). The fruits range from green to yellow, orange, and deep red. The fruits are edible, although they are extremely hot. Thai ornamental hot peppers have a Scoville rating of 50,000 to 100,000.

The ornamental pepper seeds were surface sterilized with $1 \%(\mathrm{w} / \mathrm{v})$ sodium hypochlorite for $15 \mathrm{~min}$ and rinsed thoroughly three times with distilled water. The sterilized seeds were sown into 70-cell plastic trays filled with a media consisting of peat and perlite in the ratio of 4:1 and grown on a greenhouse bench. The trays were 
irrigated as needed. Uniform 4-week-old pepper seedlings were transplanted into plastic pots $(12 \mathrm{~cm}$ in diameter and $11 \mathrm{~cm}$ in deep) filled peat/perlite substrate in the ratio of $4: 1$. The pots were irrigated regularly and fertilized with $20-20-20$ N-P-K soluble fertilizer to supply $200 \mathrm{mg} . \mathrm{L}^{-1} \mathrm{~N}$ weekly.

\section{Biostimulant treatment}

Stimplex ${ }^{\circledR}$ liquid commercial concentrate of Ascophyllum nodosum (Acadian Seaplants Limited, Dartmouth, NS, Canada) was used as biostimulant in this experiment. Stimplex ${ }^{\circledR}$ contains $99 \%$ Ascophyllum nodosum extract, $0.01 \%$ kinetin and other ingredients determined to be non-hazardous. Three days after transplanting, ornamental pepper plants were treated with Stimplex ${ }^{\circledR}$ crop biostimulant as either soil drench or foliar spray at $0,0.25,0.50,0.75$, and $1.0 \mathrm{ml} . \mathrm{L}^{-1}$ concentrations containing of $0.1 \%$ Tween 20 (Sigma Chemical Co., St. Louis, Mo.) as a wetting agent. Plants sprayed or drenched with water containing $0.1 \%$ Tween 20 served as the control. Foliar applications were applied with an atomizer to run-off, ensuring that upper and lower leaf surfaces were fully wetted, and the soil surface was covered during application to prevent soil contamination. Soil drench treatments were applied using $100 \mathrm{~mL}$ of biostimulant solution per pot. Treatments were repeated at 10-day intervals until week 10 (i.e., the end of the experiment).

\section{Plant growth components evaluated}

At the end of 10-week growth period, all replicates per treatment sampled for measurement of number of true leaves, leaf area using LI-3100C portable area meter (LI-COR Biosciences, Lincoln, Nebraska, USA), open flowers (at anthesis), and leaf relative chlorophyll content of three recently mature leaves per plant using Minolta SPAD-502 Plus chlorophyll meter; Minolta Camera Co., Osaka, Japan), crown diameter, plant shoot fresh and dry weight, root fresh and dry weight, plant height. For dry weights, plant shoots and roots were dried separately in a forced air oven at $70{ }^{\circ} \mathrm{C}$ until dry weights remained constant.

\section{Experimental design and statistical analysis}

The treatments were arranged in a complete randomized design. One pot represented the experimental unit and each treatment contained five replicate pots. All data were subjected to analysis of variance using the general linear model program of SAS (version 9.1.3; SAS Institute, Cary, NC). Means comparison was performed using the Tukey's honestly significant difference test at $P \leq 0.05$.

\section{Results}

\section{Stem diameter}

The effect of Stimplex ${ }^{\circledR}$ treatments on basal stem diameter of ornamental pepper is depicted in Figure 1. There was a significant difference $\left(P \leq 0.01\right.$ between Stimplex ${ }^{\circledR}$ levels in the increment of stem diameter at the end of 10-week growth period. The stem diameter ranged from 3.49 to $4.40 \mathrm{~mm}$ and the average stem diameter was $3.98 \mathrm{~mm}$. Ornamental pepper plants treated with 0.75 and $1.00 \mathrm{ml}^{-\mathrm{L}^{-1}}$ Stimplex ${ }^{\circledR}$ exhibited the highest increment of stem diameter ( 4.33 and $4.40 \mathrm{~mm}$, respectively). The plants treated 
with $0 \mathrm{ml} . \mathrm{L}^{-1}$ Stimplex ${ }^{\circledR}$ (control) had the lowest increment of stem diameter $(3.49 \mathrm{~mm}$ ), which was closely followed by plants treated with 0.25 and $0.50 \mathrm{ml}^{-\mathrm{L}^{-1}}$ Stimplex ${ }^{\circledR}$ treatments (Fig. 1). Both spray and drench treatments significantly increased stem diameter, but variation in method of application was not significant. Interaction between Stimplex ${ }^{\circledR}$ levels and application methods were also found non-significant for stem diameter.

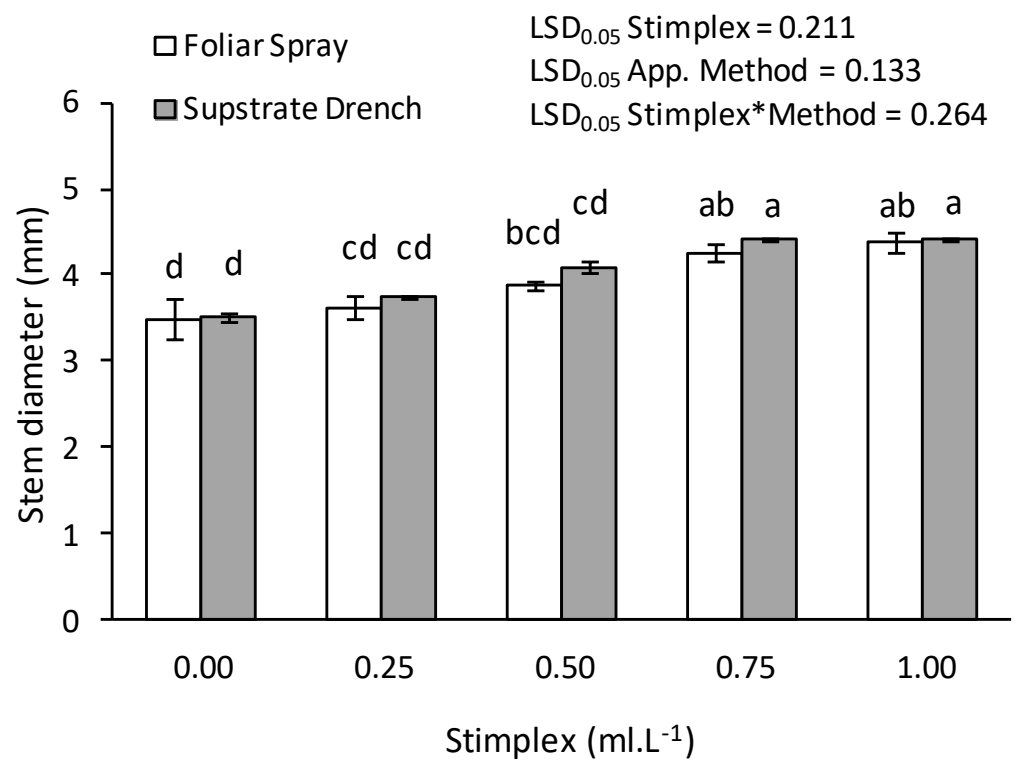

Figure 1. Effect of Stimplex ${ }^{\circledR}$ treatments applied as foliar spray and substrate drench on stem diameter of ornamental pepper. Levels not connected by same letter are significantly different at $P \leq 0.01$ by Tukey's honestly significant difference test. Values represent average $(n=5$ plants); bars represent standard error

\section{Plant height}

Application of Stimplex ${ }^{\circledR}$ significantly increased plant height $(P \leq 0.01)$. As shown in Figure 2, plant height ranged from 19.18 to $26.43 \mathrm{~cm}$ and the average plant height was $23.01 \mathrm{~cm}$ at the end of 10 -week growth period. Ornamental pepper plants treated with 0.75 and $1.00 \mathrm{ml} . \mathrm{L}^{-1}$ Stimplex ${ }^{\circledR}$ treatments exhibited the greatest increment of plant height (26.16 and $26.43 \mathrm{~cm}$, respectively). The plants treated with $0 \mathrm{ml}^{-L^{-1}}$ Stimplex $^{\circledR}$ (control) had the lowest plant height value $(19.18 \mathrm{~cm})$, which was closely followed by plants treated with 0.25 and $0.50 \mathrm{ml}^{-L^{-1}}$ Stimplex $^{\circledR}$ treatments (Fig. 2). Variation in method of application was significant $(P \leq 0.01)$ and the substrate drench method was found to be significantly effective than the foliar spray application in terms of plant height (Fig. 2). No significant interaction effect between Stimplex ${ }^{\circledR}$ levels and application methods were observed for the plant height.

\section{Number of leaves}

The effect of Stimplex ${ }^{\circledR}$ treatments on number of leaves per plant is presented in Figure 3. The number of leaves ranged from 41.00 to 46.00 leaves per plant and the average number of leaves was 43.63 at the end of 10-week growth period (Fig. 3). Application of Stimplex ${ }^{\circledR}$ significantly increased the number of leaves $(P \leq 0.01)$. Ornamental pepper plants treated with 0.75 and $1.00 \mathrm{ml}^{-\mathrm{L}^{-1}}$ Stimplex $^{\circledR}$ treatments 


$$
-4365-
$$

showed the highest number of leaves (45.62 and 46.00, respectively), whereas the values of plants treated with 0.25 and $0.50 \mathrm{ml} . \mathrm{L}^{-1}$ Stimplex ${ }^{\circledR}$ treatments were not significantly different than the values of control plants treated with 0 ml.L - $^{-1}$ Stimplex ${ }^{\circledR}$ (41.00). Variation in method of application was significant $(P \leq 0.05)$ and the substrate drench method was found to be significantly effective than the foliar spray application in terms of number of leaves (Fig. 3). No significant interaction effect between Stimplex ${ }^{\circledR}$ levels and application methods were observed for number of leaves.

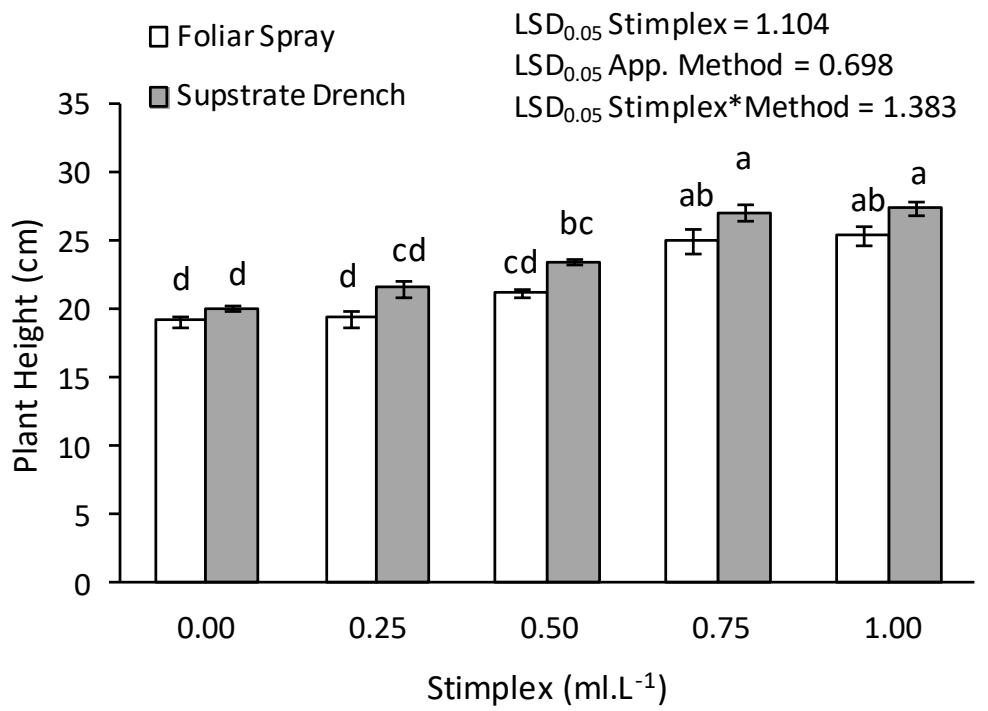

Figure 2. Effect of Stimplex ${ }^{\circledR}$ treatments applied as foliar spray and substrate drench on plant height of ornamental pepper. Levels not connected by same letter are significantly different at $P \leq 0.01$ by Tukey's honestly significant difference test. Values represent average $(n=5$ plants); bars represent standard error

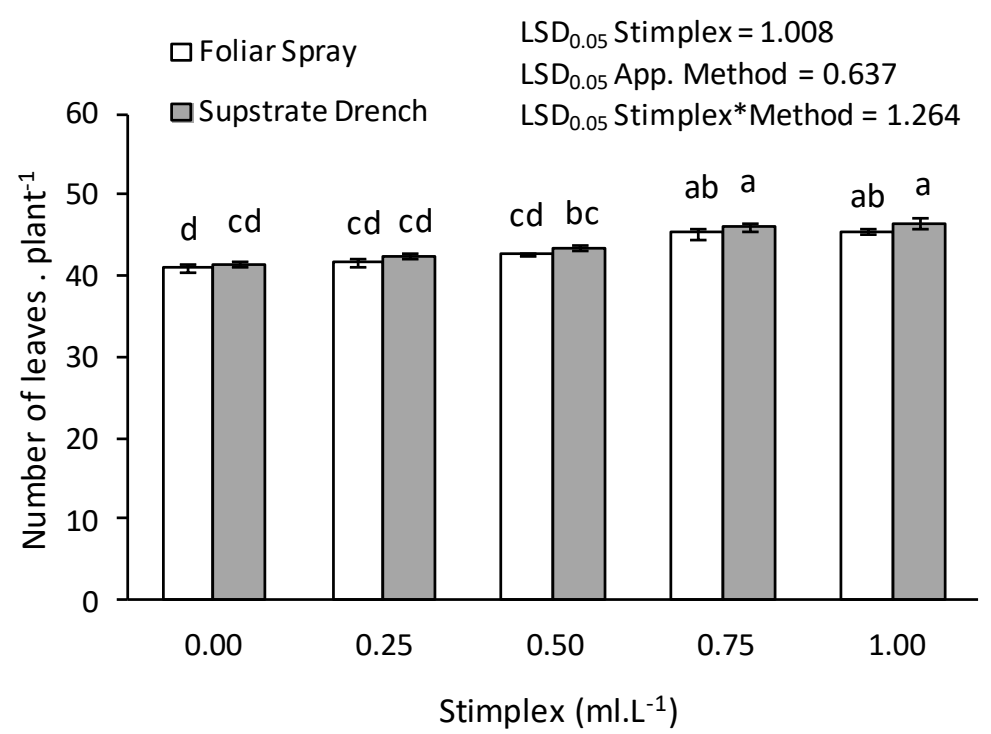

Figure 3. Effect of Stimplex ${ }^{\circledR}$ treatments applied as foliar spray and substrate drench on number of leaves of ornamental pepper. Levels not connected by same letter are significantly different at $P \leq 0.01$ by Tukey's honestly significant difference test. Values represent average $(n=5$ plants $)$; bars represent standard error 


\section{Leaf area}

The average leaf area per plant is illustrated in Figure 4. The leaf area per plant ranged from 235 to $353 \mathrm{~cm}^{2}$ plant ${ }^{-1}$ and the average leaf area was $294 \mathrm{~cm}^{2}$ plant $^{-1}$ at the end of 10 -week growth period. The plants treated with 0.75 and $1.00 \mathrm{ml}^{-L^{-1}}$ Stimplex $^{\circledR}$ treatments produced the highest leaf area (348 and $353 \mathrm{~cm}^{2}$ plant ${ }^{-1}$, respectively), whereas the leaf area values of plants treated with 0.25 and $0.50 \mathrm{ml}^{-\mathrm{L}^{-1}}$ Stimplex $^{\circledR}$ treatments were not significantly different than the values of control plants treated with 0 ml.L $\mathrm{L}^{-1}$ Stimplex ${ }^{\circledR}\left(235 \mathrm{~cm}^{2}\right.$ plant $\left.^{-1}\right)$. Variation in method of application was significant $(P \leq 0.05)$ and the substrate drench method was found to be significantly effective than the foliar spray application in terms of leaf area per plant. There was no significant interaction between Stimplex ${ }^{\circledR}$ levels and application methods for the leaf area.

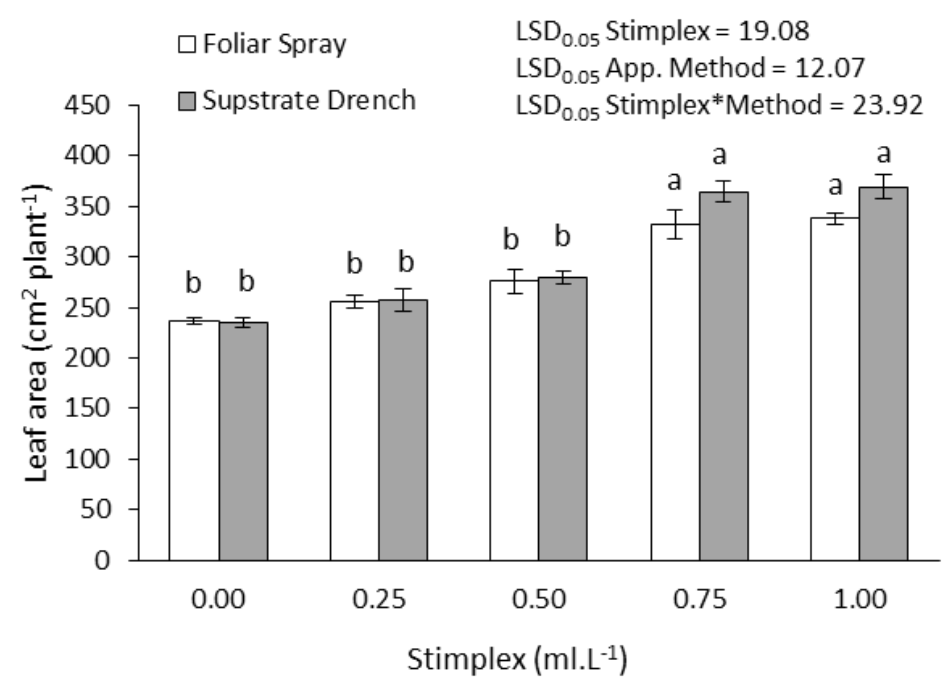

Figure 4. Effect of Stimplex ${ }^{\circledR}$ treatments applied as foliar spray and substrate drench on leaf area of ornamental pepper. Levels not connected by same letter are significantly different at $P \leq 0.01$ by Tukey's honestly significant difference test. Values represent average $(n=5$ plants); bars represent standard error

\section{Number of flowers}

Application of Stimplex ${ }^{\circledR}$ either as foliar spray or substrate drench significantly increased the number of flowers $(P \leq 0.01)$. The 0.75 and $1.00 \mathrm{ml} . \mathrm{L}^{-1}$ Stimplex $^{\circledR}$ treatments resulted in the highest number of flowers (23.62 flowers), whereas the values of plants treated with 0.25 and $0.50 \mathrm{ml} . \mathrm{L}^{-1}$ Stimplex ${ }^{\circledR}$ treatments were not significantly different than the values of control $\left(0 \mathrm{ml} . \mathrm{L}^{-1}\right.$ Stimplex $\left.{ }^{\circledR}\right)$ plants $(20.87$ flowers $)$. There were no significant differences between the two application methods of Stimplex ${ }^{\circledR}$ in the number of flowers. No significant interaction effect between Stimplex ${ }^{\circledR}$ levels and application methods were also detected for the number of flowers (Fig. 5).

\section{Chlorophyll content}

The effect of Stimplex ${ }^{\circledR}$ treatments on leaf chlorophyll content (SPAD) presented in Figure 6. Results revealed that application of Stimplex ${ }^{\circledR}$ either as foliar spray or substrate drench significantly increased leaf chlorophyll content of ornamental pepper $(P \leq 0.01)$. The plants treated with 0.75 and $1.00 \mathrm{ml}^{-\mathrm{L}^{-1}}$ Stimplex ${ }^{\circledR}$ treatments showed 
the highest number of flowers (57.86 and 58.70 SPAD, respectively). The plants treated with $0 \mathrm{ml} . \mathrm{L}^{-1}$ Stimplex ${ }^{\circledR}$ (control) had the lowest chlorophyll content (50.71 SPAD), which was closely followed by plants treated with 0.25 and $0.50 \mathrm{ml} . \mathrm{L}^{-1}$ Stimplex $^{\circledR}$ treatments (Fig. 6). There were significant differences between the two application methods of Stimplex ${ }^{\circledR}$ in the chlorophyll content. Beneficial effect of Stimplex ${ }^{\circledR}$ in enhancing chlorophyll content was more apparent in substrate drenched plants than foliar sprayed plants. There were also significant interaction effects between Stimplex ${ }^{\circledR}$ levels and application methods on chlorophyll content. The highest chlorophyll content was obtained from interactions of substrate drench $\times 0.75$ or 1.00 lg. $\mathrm{L}^{-1}$ Stimplex $^{\circledR}$ levels.

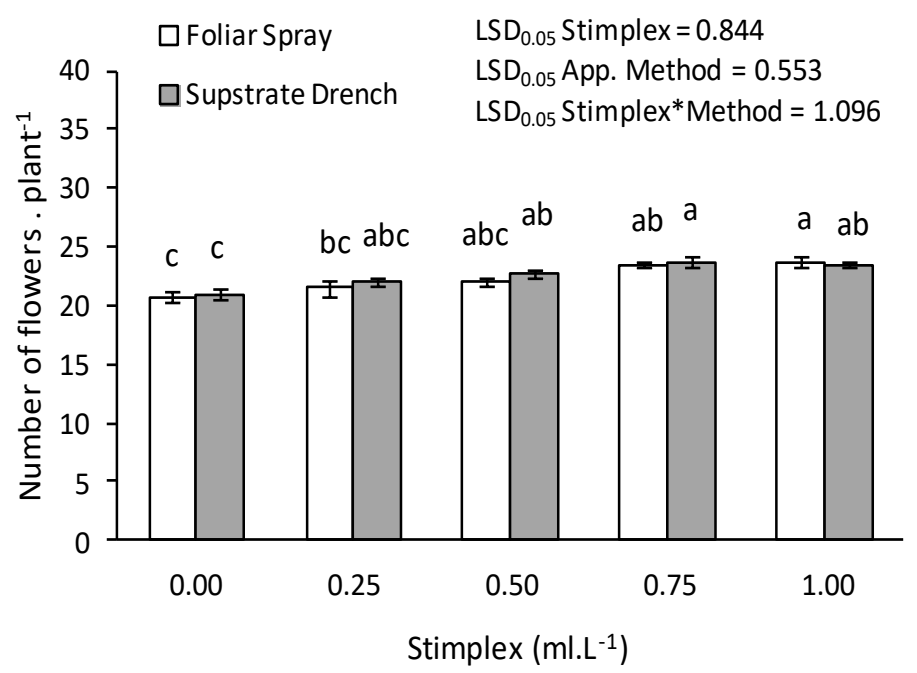

Figure 5. Effect of Stimplex ${ }^{\circledR}$ treatments applied as foliar spray and substrate drench on number of flowers of ornamental pepper. Levels not connected by same letter are significantly different at $P \leq 0.01$ by Tukey's honestly significant difference test. Values represent average $(n=5$ plants); bars represent standard error

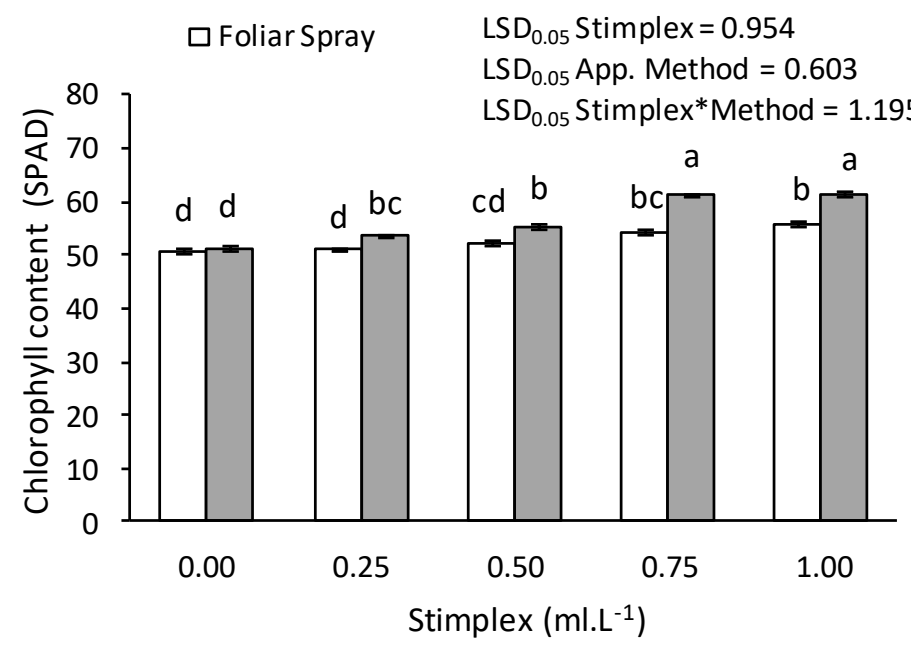

Figure 6. Effect of Stimplex ${ }^{\circledR}$ treatments applied as foliar spray and substrate drench on chlorophyll content (SPAD) of ornamental pepper. Levels not connected by same letter are significantly different at $P \leq 0.01$ by Tukey's honestly significant difference test. Values represent average ( $n=5$ plants); bars represent standard error 


\section{Shoot fresh weight}

Results indicated that application of Stimplex ${ }^{\circledR}$ either as foliar spray or substrate drench significantly increased shoot fresh weight of ornamental pepper plants $(P \leq 0.01)$. As presented in Figure 7 , the shoot fresh weight ranged from 15.67 to $20.30 \mathrm{~g}$ and the average shoot fresh weight was $22.45 \mathrm{~g}$ at the end of 10 -week growth period. Ornamental pepper plants applied with 0.75 and $1.00 \mathrm{ml}^{-\mathrm{L}^{-1}}$ Stimplex $^{\circledR}$ treatments as foliar spray or substrate drench showed the highest shoot fresh weight values (20.30 and $20.22 \mathrm{~g}$, respectively). The control plants $\left(0 \mathrm{ml} . \mathrm{L}^{-1}\right.$ Stimplex $\left.^{\circledR}\right)$ had the lowest shoot fresh weight value $(15.67 \mathrm{~g})$, which was closely followed by plants treated with $0.25 \mathrm{mg} . \mathrm{L}^{-1}$ Stimplex $^{\circledR}$ (Fig. 7). There were no significant differences between the two application methods of Stimplex ${ }^{\circledR}$ in the shoot fresh weight. No significant interaction effect between Stimplex ${ }^{\circledR}$ levels and application methods were also detected for the shoot fresh weight.

\section{Shoot dry weight}

As shown in Figure 8, the shoot dry weights ranged from 2.11 to $2.46 \mathrm{~g}$ and the average shoot dry weight was $2.29 \mathrm{~g}$ at the end of 10 -week growth period. Ornamental pepper plants treated with 0.75 and $1.00 \mathrm{ml}^{-\mathrm{L}^{-1}}$ Stimplex ${ }^{\circledR}$ treatments produced the greatest shoot dry weight values (2.45 and $2.46 \mathrm{~g}$, respectively), whereas the values of shoot dry weights of plants treated with 0.25 and 0.50 ml.L ${ }^{-1}$ Stimplex ${ }^{\circledR}$ were not significantly different than the values of control plants $(2.11 \mathrm{~g})$. Similarly to shoot fresh weight, there were no significant differences between the two application methods of Stimplex ${ }^{\circledR}$ in the shoot dry weight. No significant interaction effects between Stimplex ${ }^{\circledR}$ levels and application methods were also observed for the shoot dry weight.

\section{Root fresh weight}

Application of Stimplex ${ }^{\circledR}$ either as foliar spray or substrate drench significantly increased root fresh weight of ornamental pepper plants $(P \leq 0.01)$. The 0.75 and $1.00 \mathrm{ml} . \mathrm{L}^{-1} \mathrm{Stimplex}^{\circledR}$ treatments resulted in the greatest root fresh weight values (7.31 and $7.49 \mathrm{~g}$, respectively). The plants treated with $0 \mathrm{ml} . \mathrm{L}^{-1}$ Stimplex $^{\circledR}$ (control) had the lowest root fresh weight $(5.69 \mathrm{~g})$, which was closely followed by plants treated with 0.25 and $0.50 \mathrm{ml}^{-\mathrm{L}^{-1}}$ Stimplex $^{\circledR}$ treatments (Fig. 9). There were significant differences between the two application methods of Stimplex ${ }^{\circledR}$ in the root fresh weight $(P \leq 0.01)$. Beneficial effect of Stimplex ${ }^{\circledR}$ in enhancing root fresh weight was more evident in substrate drenched plants than foliar sprayed plants. No significant interaction effect between Stimplex ${ }^{\circledR}$ levels and application methods were found for the root fresh weight.

\section{Root dry weight}

The root dry weights ranged from 0.73 to $0.90 \mathrm{~g}$ and the average root dry weight was $0.81 \mathrm{~g}$ at the end of 10-week growth period (Fig. 10). Results indicated that application of Stimplex ${ }^{\circledR}$ either as foliar spray or substrate drench significantly increased root dry weight of ornamental pepper $(P \leq 0.01)$. The plants treated with 0.75 and 1.00 ml.L ${ }^{-1}$ Stimplex ${ }^{\circledR}$ treatments showed the greatest root dry weight values (0.87 and $0.90 \mathrm{~g}$, respectively). The plants treated with $0 \mathrm{ml} . \mathrm{L}^{-1}$ Stimplex $^{\circledR}$ (control) 
had the lowest root dry weight value $(0.73 \mathrm{~g})$, which was closely followed by plants treated with 0.25 and $0.50 \mathrm{ml}^{-\mathrm{L}^{-1}}$ Stimplex ${ }^{\circledR}$ treatments (Fig. 10). There were significant differences between the two application methods of Stimplex ${ }^{\circledR}$ in the root dry weight $(P \leq 0.05)$. Substrate drench applications gave better response and increased the number of flowers more than foliar applications. No interaction effect was detected between Stimplex ${ }^{\circledR}$ levels and application methods on the root dry weight of ornamental pepper plants.

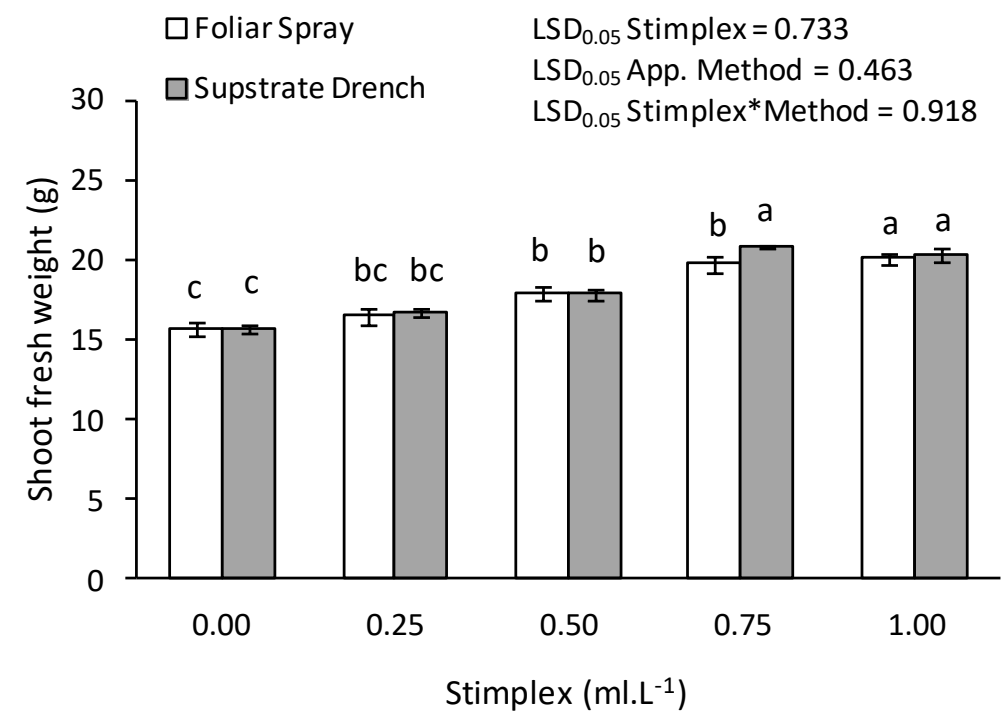

Figure 7. Effect of Stimplex ${ }^{\circledR}$ treatments applied as foliar spray and substrate drench on shoot fresh weight of ornamental pepper. Levels not connected by same letter are significantly different at $P \leq 0.01$ by Tukey's honestly significant difference test. Values represent average $(n=5$ plants); bars represent standard error

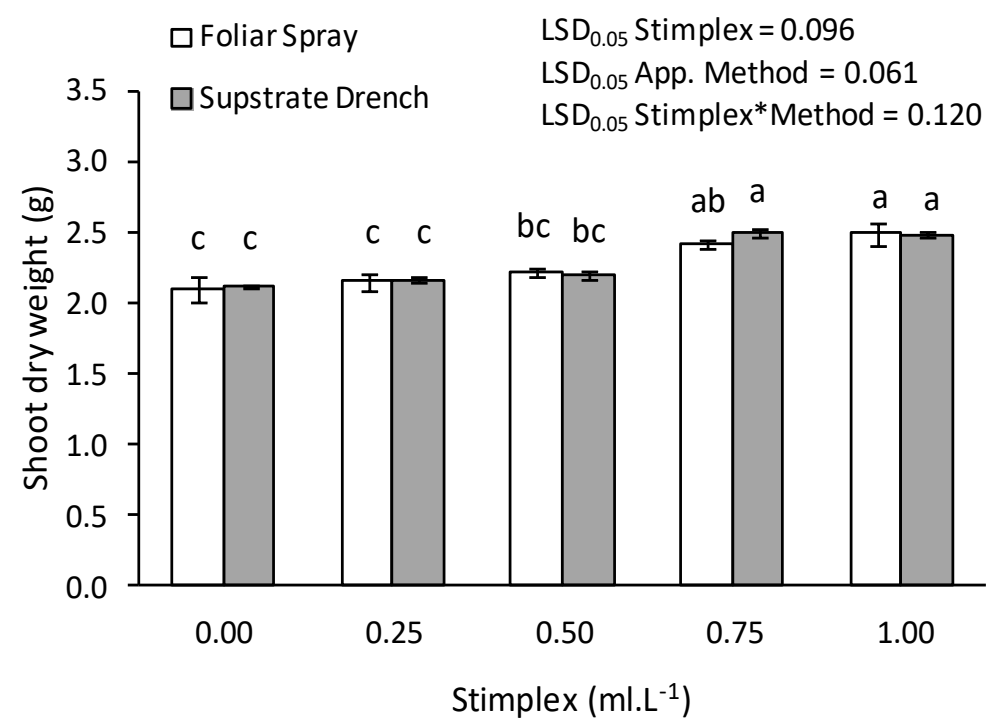

Figure 8. Effect of Stimplex ${ }^{\circledR}$ treatments applied as foliar spray and substrate drench on shoot dry weight of ornamental pepper. Levels not connected by same letter are significantly different at $P \leq 0.01$ by Tukey's honestly significant difference test. Values represent average $(n=5$ plants); bars represent standard error 


$$
-4370-
$$

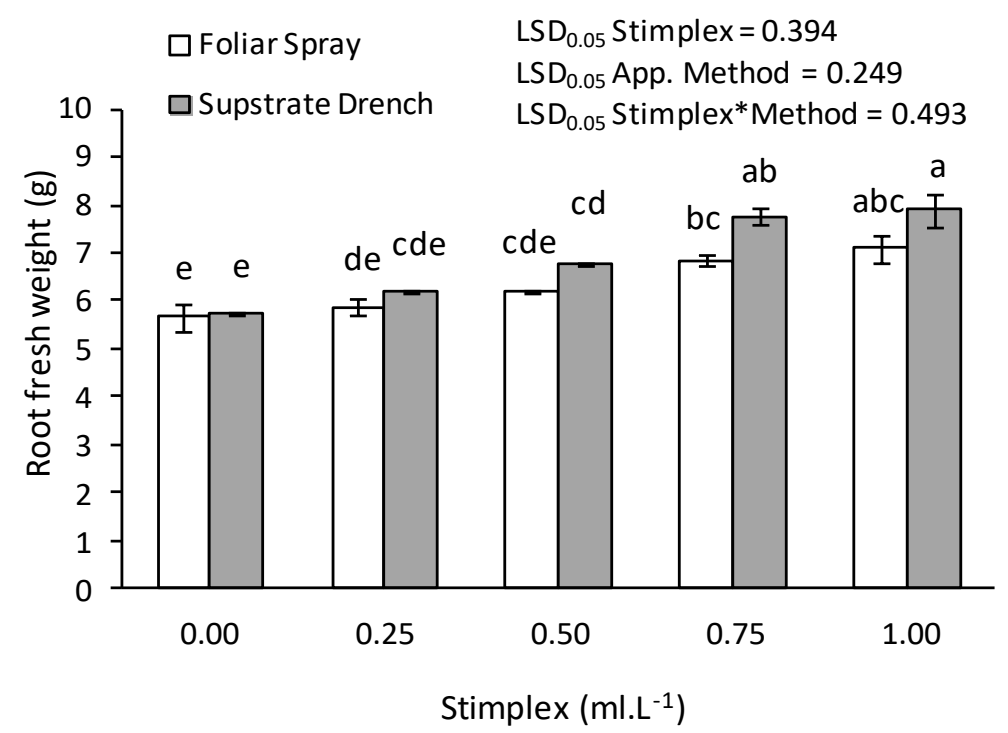

Figure 9. Effect of Stimplex ${ }^{\circledR}$ treatments applied as foliar spray and substrate drench on root fresh weight of ornamental pepper. Levels not connected by same letter are significantly different at $P \leq 0.01$ by Tukey's honestly significant difference test. Values represent average $(n=5$ plants); bars represent standard error

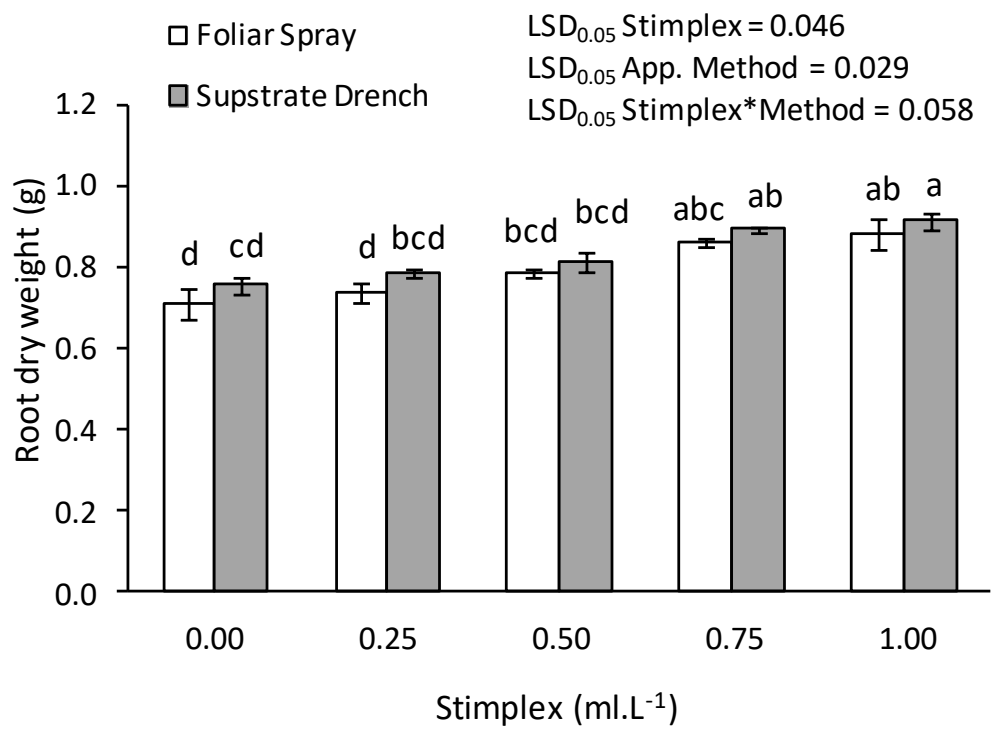

Figure 10. Effect of Stimplex ${ }^{\circledR}$ treatments applied as foliar spray and substrate drench on shoot dry weight of ornamental pepper. Levels not connected by same letter are significantly different at $P \leq 0.01$ by Tukey's honestly significant difference test. Values represent average $(n=5$ plants); bars represent standard error

\section{Discussion}

Seaweed concentrates have been reported to trigger early flowering and to increase number of flowers in crop plants. In this study, Stimplex ${ }^{\circledR}$ treatments increased the flower number in ornamental pepper plants. The promotion of flowering following application of Stimplex ${ }^{\circledR}$ was observed in some other plant species For example, Li and 
Mattson (2015) reported that substrate drench at 5-10 ml.L $\mathrm{L}^{-1}$ significantly increased flower number of petunia and tomato. They used higher concentrations than ours. This could be explained by the fact that different plant species can have different responses to the application methods and rates of seaweed concentrates. Sarhan and Ismael (2014) also verified positive effects of seaweed extract on flower number by reporting that treatment with seaweed extracts significantly enhanced number of flowers and fruit setting percentage in cucumber. This can be attributed to the fact that the seaweed extracts have been reported to contain significant amounts of auxins, cytokinins, and betaines, which affect cell division during the early stages of growth along with the induction of flower formation and number (Roussos et al., 2009).

In the current study, the Stimplex ${ }^{\circledR}$ treated ornamental pepper plants had higher leaf chlorophyll content (SPAD) than those in the control plants. Leaf chlorophyll content was enhanced following seaweed application in a number of previous studies (Eris et al., 1995; Blunden et al., 1997; Spinelli et al., 2010; Fan et al., 2013; Jannin et al., 2013). It was also previously shown that cytokinin-like effects and betaines in seaweed (A. nodosum) extracts might be responsible for this effect (Whapham et al., 1993). Blunden et al. (1997) reported that application of an extract of A. nodosum resulted in higher concentrations of chlorophyll in the leaves of tomato, bean, wheat, barley, and maize plants in comparison to control plants. They also suggested that the enhanced leaf chlorophyll content of plants treated with seaweed extract was dependent on the betaines present. Betaines, while not traditionally included among the known classical plant hormones, are found in seaweeds and their extracts (MacKinnon et al., 2010). Recently, Fan et al. (2013) observed that the transcription of betaine aldehyde dehydrogenase and choline monooxygenase were greater in seaweed (A. nodosum) treated leaves compared to the control. Contrary to some earlier research findings, no beneficial effects were detected for seaweed (A. nodosum) applications on chlorophyll content of spinach grown under both normal and stress situations (Xu and Leskovar, 2015).

Numerous studies have revealed seaweed extracts promoted vegetative growth of horticultural crops (Arthur et al., 2003; Morales Payan, 2004; Spinelli et al., 2010; Kumari et al., 2011; Zodape et al., 2011; Zulaikha, 2013; Hernández-Herrera et al., 2014; Selvakumari and Venkatesan, 2017; Yildiztekin et al., 2018). In accordance with these earlier studies, application of Stimplex ${ }^{\circledR}$ to ornamental pepper plants improved stem diameter, plant height, number of leaves and leaf area, shoot fresh weight, shoot dry weight, root fresh weight and dry weight compared to the control plants in the present study. In a previous study, application of seaweed (A. nodosum) extract solution at $1 \%$ concentration to roots produced transplants with increased root length and shoot length compared to control in tomato (Poincelot, 1993). Spinelli et al. (2010) reported that seaweed extract derived by the algae A. nodosum increased the vegetative growth of strawberry up to $10 \%$. They also reported that the most significant result was the increment of the plant biomass: the shoot dry matter was increased up to $27 \%$ and root dry matter up to $76 \%$. In another study, Kumari et al. (2011) reported an increase in root length, shoot length, and fresh weight in tomato treated with drench and foliar applications of liquid seaweed extracts. Similarly, at 21 days following application, addition of $0.1 \mathrm{~g} \mathrm{~L}^{-1}$ of seaweed extract to the growth medium significantly increased spinach fresh weight and dry-matter content by $58 \%$ and $23 \%$, respectively (Fan et al., 2013). In broccoli grown in greenhouse, drench application of seaweed extracts increased leaf area, stem diameter, and both shoot and root biomass (Mattner et al., 
2013). Recently, Zermeno-Gonzalez et al. (2015) reported that the application of biological fertilizers derived from seaweed extracts to the soil and foliage on forage maize resulted in an increase in plant height $(17.3 \%)$, stem diameter $(10.5 \%)$ and plant dry weight $(14.8 \%)$ compared to the control plants. In the study conducted by $\mathrm{Xu}$ and Leskovar (2015), A. nodosum seaweed extract treatments increased leaf fresh weight and dry weight.

It is possible that the beneficial effects of Stimplex ${ }^{\circledR}$ on growth parameters could be ascribed to the presence of macro and micro nutrients as well as growth promoting substances like cytokinins other constituents in the seaweed extract. Seaweed ingredients contains some macro and microelement nutrients, vitamins, amino acids, auxins, and cytokinins that affect cellular metabolism in treated plants, leading to enhanced growth (Crouch and van Staden, 1993; Khan et al., 2009; Craigie, 2011; Spann and Little, 2010; du Jardin, 2015). Zodape et al. (2011) have indicated that increased plant height of tomato treated with seaweed sap might be due the macro and micro nutrients as well as growth promoting substances like cytokinin promoting growth. Ramamoorthy et al. (2007) indicates that application of seaweed extract as foliar spray enhances the growth of the plants by making the growth promoting substances available to the plants through absorption and translocation. Rayorath et al. (2008) provided evidence that components of the commercial seaweed (A. nodosum) extracts regulate the concentration and translocation of auxins which could account for the enhanced plant growth. Khan et al. (2011) reported that that Stimplex ${ }^{\circledR}$ treatment resulted in increased cytokinin-like responses in Arabidopsis thaliana plants, which suggests that the seaweed extracts have compounds that may have contributed to cytokinin-like activity. Cytokinins induce cell division and proliferation, increasing the sink activity of roots, resulting in growth stimulation (Nelson and Van Staden, 1984). Increases in lateral root formation, total root volume, and root length have been observed and attributed to the presence of auxins and cytokinins in seaweed extracts (Crouch and Staden, 1993; Stirk and van Staden, 1997; Arthur et al., 2003; Khan et al., 2011; Sarhan and Ismael, 2014; Vijayanand et al., 2014).

\section{Conclusion}

Broadly, application of seaweed extracts as organic biostimulant has received a greater acceptance in agriculture because of their potent plant growth-enhancing properties. The interest in seaweed extracts to enhance agricultural productivity continues to grow globally. A number of commercial seaweed extract products are available for use in agricultural and horticultural crops. The application of Stimplex ${ }^{\circledR}$ seaweed extract $\left(0.75\right.$ and $\left.1.00 \mathrm{ml} . \mathrm{L}^{-1}\right)$ to the growing substrate and foliage caused improvement in plant growth parameters of ornamental pepper. The growth parameters increased with increasing concentrations of Stimplex ${ }^{\circledR}$, up to $0.75 \mathrm{ml} . \mathrm{L}^{-1}$, but increasing concentration beyond $0.75 \mathrm{ml} . \mathrm{L}-1$ did not have any further effect on plant growth. The results of this study indicate that Stimplex ${ }^{\circledR}$ may be a viable tool for improving growth of ornamental pepper plants. Furthermore, the preparation of the product is handy and it has no hazardous side effects and offers ecofriendly production of the agricultural produce. However, further study is needed before adopting this practice. 


\section{REFERENCES}

[1] Adbel-Mawgoud, A. M. R., Tantawy, A. S., Hafez, M. M., Habib, H. A. M. (2010): Seaweed extract improves growth, yield and quality of different watermelon hybrids. Journal of Agricultural and Biological Sciences 6(2): 161-186.

[2] Ali, N., Farrell, A., Ramsubhag, A., Jayaraman, J. (2016): The effect of Ascophyllum nodosum extract on the growth, yield and fruit quality of tomato grown under tropical conditions. - Journal of Applied Phycology 28: 1353-1362.

[3] Anonymous (2017): Biostimulant Market - Global Market Analysis, Forecasts and Trends (2017-2022). - https://www.mordorintelligence.com/industry-reports/globalplant-biostimulant-market-industry (access date: 10.03.2018).

[4] Anonymous (2018): Stimplex concentrated crop biostimulant for health and vigour. https://ilex-envirosciences.com/wp-content/uploads/2016/09/Stimplex-1610-iii.pdf (access date: 12.02.2018).

[5] Arthur, G. D., Stirk, W. A., Van Staden, J. (2003): Effect of a seaweed concentrate on the growth and yield of three varieties of Capsicum annuum. - South African Journal of Botany 69: 207-211.

[6] Basak, A. (2008): Effect of preharvest treatment with weaweed products, Kelpak ${ }^{\circledR}$ and Goemar BM $86^{\circledR}$ on fruit quality in apple. - International Journal of Fruit Sciences 8(1-2): $1-14$.

[7] Blunden, G., Jenkins, T., Liu, Y. (1997): Enhanced leaf chlorophyll levels in plants treated with seaweed extract. - Journal of Applied Phycology 8: 535-543.

[8] Calvo, P., Nelson, L., Kloepper, J. W. (2014): Agricultural uses of plant biostimulants. Plant and Soil 383: 3-41.

[9] Chouliaras, V., Tasioula, M., Chatzissavvidis, C., Therios, I., Tsabolatidou, E. (2009): The effects of a seaweed extract in addition to nitrogen and boron fertilization on productivity, fruit maturation, leaf nutritional status and oil quality of the olive (Olea europaea L.) cultivar Koroneiki. - Journal of the Science of Food and Agriculture 89: 984-988.

[10] Craigie, J. S. (2011): Seaweed extract stimuli in plant science and agriculture. - J. Appl. Phycol. 23: 371-393.

[11] Crouch, I. J., van Staden, J. (1993): Evidence for the presence of plant growth regulators in commercial seaweed products. - Plant Growth Regulation 13(1): 21-29.

[12] Crouch, I. J., Smith M. T., Staden, J. van, Lewis M. J., Hoad, G. V. (1992): Identification of auxins in a commercial seaweed concentrate. - Journal of Plant Physiology 139: 590594.

[13] du Jardin, P. (2015): Plant biostimulants: definition, concept, main categories and regulation. - Sci. Hortic. 196: 3-14.

[14] EBIC (2018): European Biostimulants Industry Council. - http://www.biostimulants.eu (access date: 12.02.2018).

[15] Eris, A., Sivritepe, H. Ö., Sivritepe, N. (1995): The effects of seaweed (Ascophyllum nodosum) extract on yield and quality in peppers. - Acta Horticulturae 412: 185-192.

[16] Fan, D., Hodges, D. M., Critchley, A. T., Prithiviraj, B. (2013): A commercial extract of Brown Macroagla (Ascophyllum nodosum) affects yield and the nutritional quality of spinach in vitro. - Communications in Soil Science and Plant Analysis 44: 1873-1884.

[17] Hernández-Herrera, R. M., Santacruz, F., RuizLopez, M. A. (2014): Effect of liquid seaweed extracts on growth of tomato seedlings (Solanum lycopersicum L.). - Journal of Applied Phycology 26(1): 619-628.

[18] Jannin, L., Arkoun, M., Etienne, P. et al. (2013): Brassica napus growth is promoted by Ascophyllum nodosum (L.) Le Jol. Seaweed extract: microarray analysis and physiological characterization of N, C, and S metabolisms. - Journal of Plant Growth Regulation 32: 31-52. 
[19] Kauffman, G. L., Kneivel, D. P., Watschke, T. L. (2007): Effects of a biostimulant on the heat tolerance associated with photosynthetic capacity, membrane thermostability, and polyphenol production of perennial ryegrass. - Crop Science 47: 261-267.

[20] Khan, W., Rayirath, U. P., Subramanian, S., Jithesh, M. N., Rayorath, P., Hodges, D. M. et al. (2009): Seaweed extracts as biostimulants of plant growth and development. Journal of Plant Growth Regulation 28: 386-399.

[21] Khan, W., Hiltz, D., Critchley, A. T., Prithiviraj, B. (2011): Bioassay to detect Ascophyllum nodosum extract-induced cytokinin-like activity in Arabidopsis thaliana. Journal of Applied Phycology 23: 409-414.

[22] Kumari, R., Kaur, I., Bhatnagar, A. K. (2011): Effect of aqueous extract of Sargassum johnstonii Setchell \& Gardner on growth, yield and quality of Lycopersicon esculentum Mill. - Journal of Applied Phycology 23: 623-633.

[23] Li, Y., Mattson, N. S. (2015): Effects of Seaweed extract application rate and method on post-production life of petunia and tomato transplants. - HortTechnology 25(4): 505-510.

[24] MacKinnon, S. A., Craft, C. A., Hiltz, D., Ugarte, R. (2010): Improved methods of analysis for betaines in Ascophyllum nodosum and its commercial seaweed extracts. - J Appl Phycol 22: 489-494.

[25] Mattner, S. W., Wite, D., Riches, D. A., Porter, I. J., Arioli, T. (2013): The effect of kelp extract on seedling establishment of broccoli on contrasting soil types in southern Victoria, Australia. - Biol Agric Hortic 29: 258-270.

[26] Morales-Payan, J. P. (2004): Influence of watering regimes, a seaweed-derived biostimulant, and Trichoderma soil amendments on ornamental pepper growth and fruit production. - Plant Growth Regulator Society of America (PGRSA) 32(58): 69 (Abstract).

[27] Nandwani, D., Dennery, S., Forbes, V., Geiger, T., Sidhu, V. (2015): Effect of biostımulants on the yield performance of organically-grown eggplant cultivars in the U. S. Virgin Islands. - Proceedings of the Caribbean Food Crops Society 51: 181-106.

[28] Nardi, S., Pizzeghello, D., Schiavon, M., Ertani, A. (2016): Plant biostimulants: physiological responses induced by protein hydrolyzed-based products and humic substances in plant metabolism. - Scientia Agricola 73(1): 18-23.

[29] Nelson, W. R., van Staden, J. (1984): The effect of seaweed concentrate on growth of nutrient-stressed greenhouse cucumbers. - HortScience 19: 81-82.

[30] Nika, W., Schmitzer, V., Jakopic, J. (2018): First fruit in season: seaweed extract and silicon advance organic strawberry (Fragaria x ananassa Duch.) fruit formation and yield. - Scientia Horticulturae 242: 103-109.

[31] Norrie, J., Keathley, J. P. (2006): Benefits of Ascophyllum nodosum marine-plant extract applications to "Thompson seedless" grape production. - Acta Hortic 727: 243-247.

[32] Poincelot, R. P., (1993): The use of a commercial organic biostimulant for bedding plant production. - Journal of Sustainable Agriculture 3(2): 99-110.

[33] Ramamoorthy K, Sujatha K, Sivasubramanium, K. (2007): Utilization of seaweed extracts for enhancing yield in black gram (Vigna mungo (L.) Hepper). - Seaweed Research and Utilisation 29: 97-100.

[34] Rayorath, P., Narayanan, J. M., Farid, A., Khan, W., Palanisamy, R., Hankins, S., Critchley, A. T., Prithiviraj, B. (2008): Rapid bioassays to evaluate the plant growth promoting activity of Ascophyllum nodosum (L.) Le Jol. using a model plany, Arabidopsis thaliana (L.) Heynh. - Journal of Applied Phycology 20: 423-429.

[35] Reitz, S. R., Trumble, J. T. (1996): Effects of cytokinin-containing seaweed extract on Phaseolus lunatus L.: Influence of nutrient availability and apex removal. - Botanica Marina 39: 33-38.

[36] Roussos, P. A., Denaxa, N. K., Damvakaris, T. (2009): Strawberry fruit quality attributes after application of plant growth stimulating compounds. - Scientia Horticulturae 119: 138-146. 
[37] Sarhan, T. Z., Ismael, S. F. (2014): Effect of low temperature and seaweed extracts on flowering and yield of two cucumber cultivars (Cucumis sativus L.). - International Journal of Agricultural and Food Research 3(1): 41-54.

[38] Sarhan, T. Z., Ali, T. A., Rasheed, SMS. (2011): Effect of bread yeast application and seaweed extract on cucumber (Cucumis sativus 1.) plant growth, yield and fruit quality. Mesopotamia Journal of Agriculture 39(2): 26-34.

[39] Selvakumari, P., Venkatesan, K. (2017): Seasonal influence of seaweed gel on growth and yield of tomato (Solanum lycopersicum Mill.) Hybrid COTH 2. - Int. J. Curr. Microbiol. App. Sci. 6(9): 55-66.

[40] Sidhu, V., Nandwani, D. (2016): Effect of Stimplex ${ }^{\circledR}$ on yield performance of tomato inorganic management system. - 4th International Agronomy Congress, Nov. 22-26, New Delhi, India. Lead Papers 4: 74-76.

[41] Sidhu, V., Nandwani, D. (2017): Effect of Stimplex ${ }^{\circledR}$ on yield performance of tomato in organic management system. - Annals of Advanced Agricultural Sciences 1(1): 11-15.

[42] Spann, T. M., Little, H. A. (2010): Effect of Simplex crop biostimulant on drought tolerance of Hamlin sweet orange. - Proceedings of Florida state horticulture Society 123: $100-104$.

[43] Spinelli, F., Fiori, G., Noferini, M., Sprocatti, M., Costa, G. (2010): A novel type of seaweed extract as a natural alternative to the use of iron chelates in strawberry production. - Scientia Horticulturae 125: 263-269.

[44] Stirk, W. A., van Staden, J. (1997): Comparison of cytokinin- and auxin-like activity in some commercially used seaweed extracts. - Journal of Applied Phycology 8: 503-508.

[45] Stirk, W. A., Novak, M. S., van Staden, J. (2003): Cytokinins in macroalgae. - Plant Growth Regulation 41: 13-24.

[46] Vijayanand, N., Sivasangari Ramya, S., Rathinavel, S. (2014): Potential of liquid extracts of Sargassum wightii on growth, biochemical and yield parameters of cluster bean plant. - Asian Pacific Journal of Reproduction 3(2): 150-155.

[47] Whapham, C. A., Blunden, G., Jenkins, T., Hankins, S. D. (1993): Significance of betaines in the increase of chlorophyll content of plants treated with seaweed extract. Journal of Applied Phycology 5: 231-234.

[48] Yildiztekin, M., Tuna, A. T., Kaya, C. (2018): Physiological effects of the brown seaweed (Ascophyllum nodosum) and humic substances on plant growth, enzyme activities of certain pepper plants grown under salt stress. - Acta Biologica Hungarica 69(3): 325-335.

[49] Xu, C., Leskovar, D. I. (2015): Effects of A. nodosum seaweed extracts on spinach growth, physiology and nutrition value under drought stress. - Scientia Horticulturae 183: 39-47.

[50] Zermeno-Gonzalez, A., Omar Cárdenas-Palomo, J., Ramírez, H., Benavides-Mendoza, A., Cadena-Zapata, M., Campos-Magaña, S. (2015): Biological fertilization of maize. Revista Mexicana de Ciencias Agrícolas 12: 2399-2408.

[51] Zhang, X., Ervin, E. H. (2004): Cytokinin-containing seaweed and humic acid extracts associated with creeping bentgrass leaf cytokinins and drought resistance. - Crop Sci. 44: 1737-1745.

[52] Zodape, S. T., Gupta, A., Bhandari, S. C. (2011): Foliar application of seaweed sap as biostimulant for enhancement of yield and quality of tomato (Lycopersicon esculentum Mill.). - Journal of Scientific \& Industrial Research 70: 215-219.

[53] Zulaikha, R. I. (2013): Effect of foliar spray of ascorbic acid, Zn, seaweed extracts (sea) force and biofertilizers (EM-1) on vegetative growth and root growth of Olive (Olea europaea L.) transplants cv. HojBlanca. - International Journal of Pure and Applied Sciences and Technology 17: 79-89. 